\title{
The memory of an outrageous public health scandal
}

\author{
Sally de França Lacerda Rolim ${ }^{1}$ iD, Claudio Gleidiston Lima da Silva1 ${ }^{1}$, \\ Fabian Danilo Unigarro Ramirez² ${ }^{\text {(D) }}$, Raul Cesar Fortaleza Pinheiro² (D), \\ Juliane dos Anjos de Paula ${ }^{3}$ iD, Nádia Nara Rolim Lima ${ }^{4}$, Modesto Leite Rolim Neto ${ }^{5}$ (iD
}

${ }_{1}^{1}$ Post-Doctorate by the Post-Graduate Program in Health Sciences - ABC Medical School - FMABC

${ }^{2}$ Medical Student at Federal University of Cariri - UFCA

${ }^{3} \mathrm{PhD}$ in Health Sciences - ABC Medical School - FMABC

${ }^{4}$ Post-Doctorate by the Neuro-Psychiatry Program at the Federal University of Pernambuco - UFPE

${ }^{5}$ Post-Doctorate in Public Health by the Faculty of Public Health of the São Paulo University -USP

Edited by:

Marcelo Moraes Valença
Keywords:

Psychiatric Repercussions

Mental Health

Oxygen

Public Health

Anxiety

\begin{abstract}
Introduction

Manaus is an isolated city, localized in the hearth of the Amazonas rainforest, with two million inhabitants, a big territorial extension, distant from neighbor cities and next to the shores of Negro and Solimões rivers. The access overland is difficult, which obligates the oxygen tanks be transported by river or air. This created and enormous logistical problem, added to the neglect of the Federal Government with the northern region of the country.

Objective

Analyze what are the psychiatric repercussions on the explosion of in the lack of oxygen in Manaus, capital of the Amazonas, Brazil.

Methods

Studies were identified using large-circulation international journals.

Results

A scandal is happening. This situation is creating a grief community - particular grief became a common and public one - to the memory of an outrageous public health scandal. Therefore, dramatic stories of families of patients and the overwhelmed healthcare professionals shared on the social media and local press brings glimpses of the angst of this chaos. An entire wing of patients died caused by the oxygen depletion.

Conclusion

This situation is causing a collective hysteria, taking healthcare workers and families of patients to desperation. Fear appears to be a consequence of the feeling of powerlessness. Anxiety levels are really elevated causing direct side effects to another mental health measures.
\end{abstract}


$\mathrm{D}$ razil is the place of the second most lethal coronavirus Boutbreak in the world after the US, with the emergency services pushed to their limit (NBC News, 2021). The explosion of COVID in the biggest Brazilian State makes healthcare professionals beg for help due to the lack of oxygen in hospitals. ' In different healthcare facilities, patients with COVID-19 are dying asphyxiated caused by the oxygen depletion. The chaos arrived into Manaus, capital of the Amazonas ${ }^{2}$ shaping itself into a scenario of terror, where hospitals became suffocating chambers. In the last days, the virus mortality rate in Manaus went from 142 to 187 for each 100.000 inhabitants, almost twice the national average (100 to 100.000$)$, where more than 210.000 died due to COVID-19.3

It is important to highlight that exist four aggravating factors of this situation: the ancient and dangerous corruption inside health public policies area; the general situation of precariousness and poverty which generate more vulnerability in population; the reality of just one hospital for each five million people, with less than 40 ICU beds; political and technique incompetence, added to far-right COVID-19 deniers. It exists as well the new variant of the virus, the same as in South Africa and the UK, but the infection spread out because they created the conditions for this to happen. ${ }^{4}$

Manaus is an isolated city, localized in the hearth of the Amazonas rainforest, with two million inhabitants, a big territorial extension, distant from neighbor cities and next to the shores of Negro and Solimões rivers. The access overland is difficult, which obligates the oxygen tanks be transported by river or air. This created and enormous logistical problem, added to the neglect of the Federal Government with the northern region of the country.

Paraphrasing Debora Diniz ${ }^{5}$, a scandal is happening. Who was the sinner who put that stumbling block on those lives? The actual disorder claims for ways of imagination to hold together the grief. This situation is creating a grief community - particular grief became a common and public one - to the memory of an outrageous public health scandal. From the particular point of view of another individuals, millions of families are losing their relatives out of time.

Therefore, dramatic stories of families of patients and the overwhelmed healthcare professionals shared on the social media and local press brings glimpses of the angst of this chaos. An entire wing of patients died caused by the oxygen depletion. ${ }^{6}$ On Instagram, the psychologist Talita Rocha supplicates "Guys, I beg for your mercy. It's horrible! There's no oxygen on healthcare facilities! A lot of people are dying out there! If you have any oxygen, please, bring it to us!". The crisis occurred after the oxygen demand surpassed the last year estimated limit, in march, when the average consume was of 30.000 cubic meters. Nowadays, the demand is over 70.000 cubic meters. It is twice and a half higher than the last year average. ${ }^{8}$ The FiocruzAmazônia warned that patients who survive can suffer permanent brain damages. Premature babies had to be transferred to a neighbor city because there was no warranty of oxygen supply even for them. 9

This situation is causing a collective hysteria, taking healthcare workers and families of patients to desperation. Fear appears to be a consequence of the feeling of powerlessness. Anxiety levels are really elevated causing direct side effects to another mental health measures. ${ }^{10}$

The impact on mental health is grave given that depression, anxiety or obsessive-compulsive disorders increase depending on the severity level of symptoms caused by the loss of someone due to the lack of oxygen. ${ }^{11}$ This, makes more difficult the process of death resignation and intensifies the psychic pain of those who lost their family or friends. ${ }^{12}$ The mental exhaustion of professionals reaches alarming levels of stress and tension. ${ }^{13}$

In this context, deaths were caused by the lack of oxygen in 200 ICU beds, according to the Federal Public Ministerium (FPM). Chocking images of desperate healthcare workers, unable of avoiding death of their patients caused a national commotion. ${ }^{6,14}$ Although new supplies of oxygen arrived the city - thanks to celebrities' donations, Venezuela Government and neighbor States - the critical situation remains. The biggest hospital in Manaus - 28th of August Hospital - was surrounded by the military to avoid desperate families break into the facility. There are people inside ambulances, because there is no way to get into the hospital. The hospital is asking for families to get their own oxygen tanks. Doctors are reducing oxygen flow of their patients to deal with the shortage, as a emergency measure with big consequences. ${ }^{15,16}$

Meanwhile doctors are using manual ventilators and deciding who they are going to treat, other patients stay unassisted and dye. The race to fill up the tank of oxygen most of the tame is frustrated by the lack of the gas and families are helping ventilating manually their relatives. Some other families prefer to "treat" their patients at home and try to learn how to use oxygen for artificial breathing consulting internet forums or taking advices with a doctor friend. ${ }^{3}$ These families are 
in danger of contamination and definitely exposed to the lack of medical care, but they prefer this than watch their relatives dying asphyxiated in a hospital bed.

In the Amazonas State, this war has not only the virus as an enemy. On the other side there is the lack of assistance and supplies, the government denial, poverty and misery, corruption into the public health and the historic neglect of the Federal Government with the northern region of Brazil. The outcomes of this war are still unmeasurable, but is possible to predict the psychological "handicap" of the Amazonas population. Would not be the time to think about preventive actions to reduce and minimize the emotional suffering? In general, these actions are still not included on the immediate and emergency assistance provided to the population, despite the clearness of the emotional damage, which means it is necessary to elaborate new public policies which promote interdisciplinary actions prioritizing mental healthcare.

The situation Manaus is going through can be considered as disaster, since for the Brazilian Civil Defense disasters are situation that harm and cause damages to human life, being classified as natural, technological, social and war disasters. ${ }^{17}$ Can this situation not be considered as a social disaster? As Bindé and Carneiro ${ }^{18}$ suggested, the efforts to be made refer to as the preventive phase as well as the management of the occurrence, by analyzing the individual and collective behavior of the population intertwined with the incident and the emergency actions directed to the families who suffered emotional and financial losses.

\section{Conflict of interest}

The authors declare that they have no competing interests

\section{Acknowledgment}

The authors would like to thank the School of Medicine of $A B C$ - FMABC and Brazilian National Council for Scientific and Technological Development (CNPq) - institution linked to the Brazilian Department of Science, Technology.

\section{Funding}

School of Medicine of $A B C$ - FMABC and Brazilian National Council for Scientific and Technological Development (CNPq) - institution linked to the Brazilian Department of Science, Technology and Innovation to encourage research in Brazil.

Sally de França Lacerda Rolim

https://orcid.org/0000-0002-2598-1058
Claudio Gleidiston Lima da Silva

https://orcid.org/0000-0001-5730-0512

Fabian Danilo Unigarro Ramirez

https://orcid.org/0000-0003-1753-4044

Raul Cesar Fortaleza Pinheiro

https://orcid.org/0000-0002-4509-9265

Juliane dos Anjos de Paula

https://orcid.org/0000-0002-2992-988X

Nádia Nara Rolim Lima

https://orcid.org/0000-0003-1685-1232

Modesto Leite Rolim Neto

https://orcid.org/0000-0001-9379-2120

\section{References}

1. CNN. Imprensa mundial repercute colapso do sistema de saúde em Manaus [Internet]. CNN brasil; 2021 cited 2021. Available from: https://www. cnnbrasil.com.br/internacional/imprensa-mundialrepercute-sobre-o-colapso-do-sistema-de-saude-emmanaus/.

2. Sassine V. Governo Bolsonaro ignorou alertas em série sobre falta de oxigênio em Manaus [Internet]. São Paulo: Folha de São Paulo; 2021 cited 2021. Available from: https://www 1.folha.uol.com.br/ equilibrioesaude/2021/01/governo-bolsonaroignorou-alertas-em-serie-sobre-falta-de-oxigenio-emmanaus.shtml.

3. France 24. Brésil: à Manaus, l'oxygène, nerf de la guerre contre le Covid-19 [Internet]. France 24; 2021 [cited 2021. Available from: https://www. france 24.com/fr/info-en-continu/20210118. br\%C3\%A9sil-\%C3\%A0-manaus-1-oxyg\%C3\%A8nenerf-de-la-guerre-contre-le-covid-19.

4. SIR. The tragedy of Manaus suffering lack of oxygen. Archbishop Steiner: "We have been abandoned" [Internet]. AgenSIR; 2021 cited 2021. Available from: https://www.agensir.it/mondo/2021/01/18/ the-tragedy-of-manaus-suffering-lack-of-oxygenarchbishop-steiner-we-have-been-abandoned/.

5. EL PAís. O relicário de uma pandemia [Internet]. El País; 2020 cited 2021. Available from: https:// brasil.elpais.com/brasil/2020-08-08/o-relicario-deuma-pandemia.html.

6. Times TNY. Covid-19: Over Two Million Around the World Have Died From the Virus [Internet]. New York: The New York Times; 2021 cited 2021. Available from: https://www.nytimes.com/ live/2021/01/15/world/covid19-coronavirus.

7. Monde L. Si vous avez de l'oxygène, s'il vous plaît, apportez-le ! ": la ville brésilienne de Manaus sans moyens face à une seconde vague brutale [Internet]. Le Monde; 2021 cited 2021. Available from: https://www.lemonde.fr/international/ 
article/2021/01/16/au-bresil-manaus-affrontesans-moyens-une-seconde-vague-brutale-sivous-avez-de-l-oxygene-s-il-vous-plait-apportezle_6066515_3210.html.

8. Reuters. Brazil's Amazonas state running out of oxygen as COVID-19 surges [Internet]. REUTERS; 2021 cited 2021. Available from: https://www. reuters.com/article/us-health-coronavirus-brazilamazon/brazils-amazonas-state-running-out-ofoxygen-as-covid-19-surges-idUSKBN29J2SJ.

9. Aljazeera. Brazil airlifts emergency oxygen to Manaus amid COVID surge [Internet]. Al Jazeera's Coronavirus Newsletter; 2021 cited 2021. Available from: https://www.aljazeera.com/ news/2021/1/15/brazil-airlifts-emergency-oxygenin-to-pandemic-battered-manaus.

10. Lima CKT, Carvalho PMM, Lima I, Nunes J, Saraiva JS, de Souza RI, . . Neto MLR. The emotional impact of Coronavirus 2019-nCoV (new Coronavirus disease). Psychiatry Res 2020;287(112915 Doi:10.1016/i. psychres.2020.112915

11. Pan KY, Kok AAL, Eikelenboom M, Horsfall M, Jörg F, Luteijn RA, . . Penninx $B$. The mental health impact of the COVID-19 pandemic on people with and without depressive, anxiety, or obsessive-compulsive disorders: a longitudinal study of three Dutch casecontrol cohorts. Lancet Psychiatry 2021;8(2):121129 Doi:10.1016/s2215-0366(20)30491-0

12. Gonçalves Júnior J, Moreira MM and Rolim Neto ML. Silent Cries, Intensify the Pain of the Life That
13. Is Ending: The COVID-19 Is Robbing Families of the Chance to Say a Final Goodbye. Front Psychiatry 2020;11(570773) Doi:10.3389/ fpsyt. 2020.570773

14. Carvalho PMM, Moreira MM, de Oliveira MNA, Landim JMM and Neto MLR. The psychiatric impact of the novel coronavirus outbreak. Psychiatry Res 2020;286(112902 Doi:10.1016/i. psychres.2020.112902

15. NBC. Brazil's Amazonas state running out of oxygen as COVID-19 surges [Internet]. NBC News; 2021 cited 2021. Available from: https://www.nbcnews. com/news/latino/brazil-s-amazonas-state-running out-oxygen-covid-19-surges-n 1254430.

16. WSWS. Patients die of asphyxiation as hospitals in Manaus run out of oxygen [Internet]. WSWS; 2021 cited 2021. Available from: https://www.wsws.org/ en/articles/2021/01/16/braz-j16.html.

17. The Washington Post. Amazon city scrambles to provide oxygen to COVID-19 patients The Washington Post 2021 cited 2021. Available from: https://www. washingtonpost.com/world/the americas/amazon-city-scrambles-to-provide-oxygento-covid-19-patients/2021/01/15/2f33ac18-56ef11 eb-acc5-92d2819a1ccb_story.html.

18. CIVIL SND. Política Nacional de Defesa Civil. In: NACIONAL MDI, editor. 2007.

19. Bindé PJ and Carneiro C. Uma análise da ação humana a partir da perspectiva da psicologia dos desastres. J Psico 2001;32(2):25-45 